\title{
Inhibition of Escherichia coli RNase P by oligonucleotide directed misfolding of RNA
}

\author{
JESSICA L. CHILDS, ${ }^{1,3}$ ALEX W. POOLE, ${ }^{4}$ and DOUGLAS H. TURNER ${ }^{1,2,3}$ \\ ${ }^{1}$ Departments of Chemistry and ${ }^{2}$ Pediatrics, and the ${ }^{3}$ Center for Human Genetics and Molecular Pediatric Disease, University of Rochester, \\ Rochester, New York 14627, USA \\ ${ }^{4}$ Department of Molecular, Cellular, and Developmental Biology, University of Colorado-Boulder, Boulder, Colorado 80309, USA
}

\begin{abstract}
Oligonucleotide directed misfolding of RNA (ODMiR) uses short oligonucleotides to inhibit RNA function by exploiting the $\overline{a b}$ ility of RNA to fold into different strūctures with similar free energies. It is shown that the 2'-O-methyl oligonucleotide, m(CAGCCUACCCGG), can trap Escherichia coli RNase P RNA (M1 RNA) in a nonfunctional structure in a transcription mixture containing RNase P protein (C5 protein). At about $200 \mathrm{nM}$, the 12-mer thus inhibits $50 \%$ of pre-tRNA processing by RNase P. Roughly 10-fold more 12-mer is required to inhibit RNase P containing full-length, renatured RNase P RNA. Diethyl pyrocarbonate modification in the presence of 12-mer reveals increased modification of sites in and interacting with P4, suggesting a structural rearrangement of a large pseudoknot important for catalytic activity. Thus, the ODMiR method can be applied to RNAs even when folding is facilitated by a cognate protein.
\end{abstract}

Keywords: RNase P; RNA folding; antisense oligonucleotides; misfolding

\section{INTRODUCTION}

RNA is becoming an attractive target for therapeutic intervention (Pearson and Prescott 1997; Hermann and Westhof 1998 ) as its roles in more processes are being discovered. For example, rRNA is the catalytic portion of the ribosome (Ban et al. 2000), and small interfering (si) RNAs regulate gene expression (Fire et al. 1998; Montgomery et al. 1998; Nykanen et al. 2001). Oligonucleotides are one promising class of therapeutics to target RNA. Oligonucleotides can be designed from simple base-pairing rules, analogs are synthetically accessible (Freier and Altmann 1997), and their pharmacokinetic properties are relatively independent of sequence (Crooke et al. 1996).

Currently, oligonucleotide-based therapeutics are being used clinically for treatment of cytomegalovirus (Vitravene; Galderisi et al. 1999) and hematological cancers (Genasense; Stein 2001). Often, oligonucleotide therapeutics use the antisense approach to target RNA and are typically $20 \mathrm{nt}$ long. Even though antisense sequences of this length are effective in vivo, there are potential disadvantages. These include

Reprint requests to: Doug Turner, University of Rochester, Department of Chemistry, RC Box 270216, Rochester, NY 14627, USA; e-mail: turner@chem.rochester.edu.

Article and publication are at http://www.rnajournal.org/cgi/doi/ 10.1261/rna.5780503. cost of synthesis and side effects due to binding with mismatches to bystander RNAs. Studies have shown, however, that RNA function can be inhibited in vitro with shorter oligonucleotides (Testa et al. 1999; Disney et al. 2001; Childs et al. 2002).

Previously (Childs et al. 2002), we described inhibition of the Candida albicans group I self-splicing intron by oligonucleotide directed misfolding of RNA (ODMiR). The ODMiR method uses a short oligonucleotide to trap RNA in a nonfunctional structure in a transcription mixture. Kinetic traps that cause inactivation of function have been detected during renaturation of other catalytic RNAs including the hepatitis delta virus (Been et al. 1992; Chadalavada et al. 2000, 2002), the Tetrahymena thermophila group I intron (Walstrum and Uhlenbeck 1990; Celander and Cech 1991; Pan and Woodson 1998; Russell et al. 2002), and the hammerhead ribozyme (Fedor and Uhlenbeck 1990). Inactivation is often the result of misfolding of secondary structure. In some cases, proteins are known to facilitate folding of an RNA into its active conformation in an RNA-protein complex (Lambowitz and Perlman 1990; Noller et al. 1992; Weeks and Cech 1995a,b; Zhang et al. 1995; Myers et al. 1996; Clodi et al. 1999; Webb et al. 2001). Here, we describe using short oligonucleotides to induce misfolding of Escherichia coli RNase P RNA (M1 RNA) in a transcription mixture containing RNase $\mathrm{P}$ protein (C5 protein; Kole and Altman 1979). Thus, the ODMiR method can 
be used to inhibit function of an RNA even in the presence of its cognate protein.

RNase P RNAs are responsible for the site-specific removal of the $5^{\prime}$ leader stem of all pre-tRNAs (Stark et al. 1978; Kole and Altman 1979) and are essential for cell survival. In E. coli, RNase P RNA is in a 1:1 complex with RNase P protein (Talbot and Altman 1994a,b), which is required for in vivo pre-tRNA processing (Altman et al. 1993; Pace and Brown 1995). In vitro, however, RNase $P$ RNA can catalyze this reaction in the absence of protein (Guerrier-Takada et al. 1983). There is at least one slow step in the folding of E. coli RNase P RNA in which P7 undergoes a conformational change (Zarrinkar et al. 1996). More details of the folding pathway for Bacillus subtilis RNase P RNA are known, and are likely to be similar to E. coli RNase P RNA (Zarrinkar et al. 1996). They reveal that the major kinetic trap involves tertiary interactions between the catalytic (C) and specificity (S) domains (Pan and Sosnick 1997; Pan et al. 1999; Fang et al. 2002). This trap is eliminated when the domains are folded separately (Fang et al. 1999). The slow step in the folding of the catalytic domain involves consolidation of RNA structure around metal ions (Fang et al. 2002). These observations suggest that short oligonucleotides could direct RNase P RNA into an inactive structure.

\section{RESULTS}

Figure 1 (Massire et al. 1998; Brown 1999) shows the functional secondary structure of E. coli RNase P RNA. Thirtytwo DNA 12-mers complementary to consecutive regions of RNase P RNA were screened for inhibition of pre-tRNA processing in a transcription mixture containing E. coli RNase P protein (Table 1). Eight of these oligonucleotides inhibited at least $40 \%$ of pre-tRNA processing at $10 \mu \mathrm{M}$ oligonucleotide concentration. Dose-response curves were measured for all eight of these sequences as their $2^{\prime}-\mathrm{O}-\mathrm{Me}$ analogs (Table 1). The sequence $\mathrm{m}$ (CAGCCUACCCGG), which is complementary to nt 289-300, inhibited pre-tRNA processing most efficiently, with an $\mathrm{IC}_{50}$ of $200 \mathrm{nM}$ (Fig. 2). As seen in Figure 2, the absence of RNase $\mathrm{P}$ protein reduces pre-tRNA processing to about $4 \%$ in a transcription mixture. Changing the oligonucleotide sequence to shift the binding site six residues in either direction slightly increases the $\mathrm{IC}_{50}$ to $\sim 1 \mu \mathrm{M}$. Shortening the sequence to $\mathrm{m}$ (CAGCCUACCC) increases the $\mathrm{IC}_{50}$ to $\sim 2 \mu \mathrm{M}$.

RNase $\mathrm{P}$ activity is also inhibited by m(CAGCCUACCCGG) when full-length RNase P RNA is renatured in the absence or presence of $\mathrm{m}$ (CAGCCUACCCGG). As shown in Figure 3, the $\mathrm{IC}_{50}$ for $\mathrm{m}$ (CAGCCUACCCGG) when RNase $\mathrm{P}$ RNA is renatured followed by addition of $\mathrm{m}$ (CAGCCUACCCGG) and RNase P protein is about 3 $\mu \mathrm{M}$. If RNase $\mathrm{P}$ protein is not added to the reactions, however, the $\mathrm{IC}_{50}$ for $\mathrm{m}$ (CAGCCUACCCGG) is about 0.009 $\mu \mathrm{M}$. When full-length RNase P RNA is renatured in the

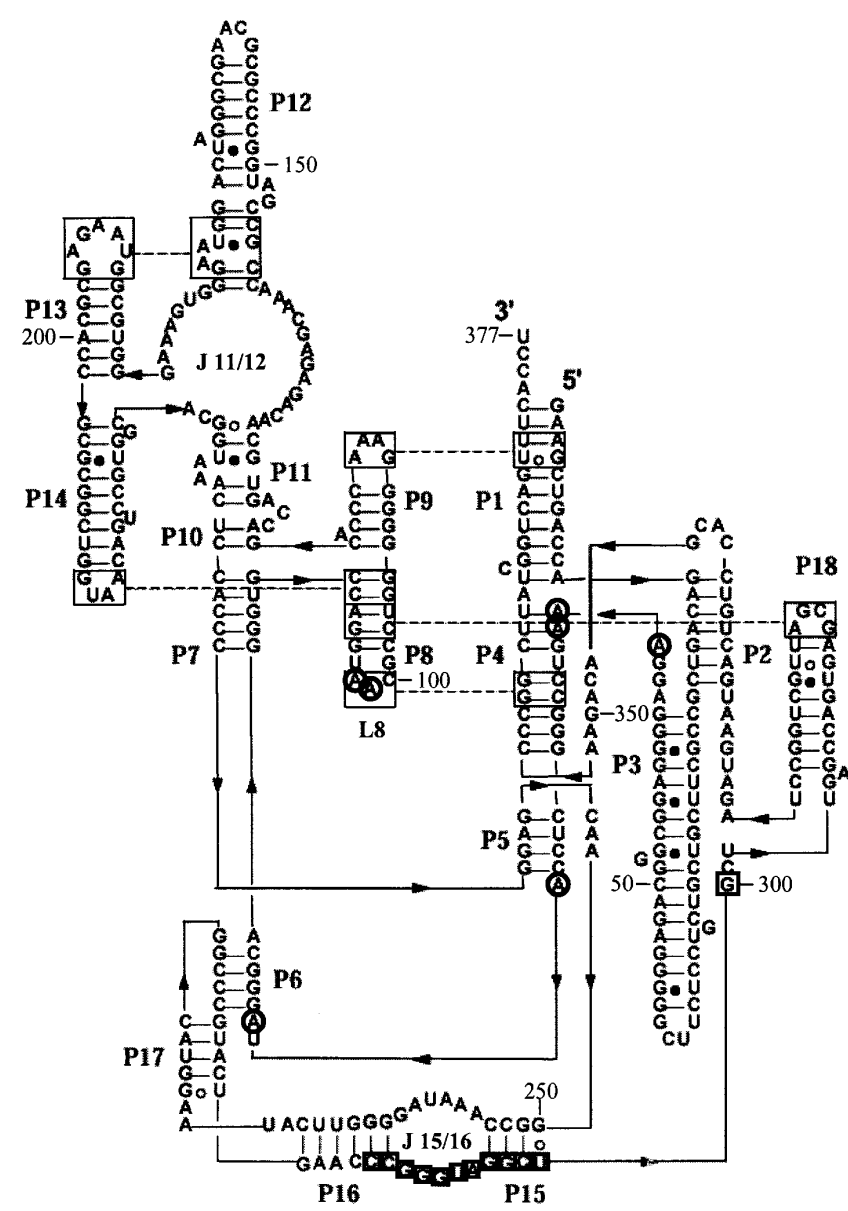

FIGURE 1. Phylogenetic structure of RNase P RNA adapted from Massire et al. (1998) and http://www-ibmc.u-strasbg.fr/upr9002/westhof/. The oligonucleotide, m(CAGCCUACCCGG), is complementary to nt 289-300 (in boxes). Circles indicate sites of increased DEPC modification in the presence of m(CAGCCUACCCGG). Large boxes connected by dashed lines indicate tertiary interactions. (Reprinted from Journal of Molecular Biology, 279: 773-793, Massire et al., (C) 1998, with permission from Elsevier.)

presence of $\mathrm{m}$ (CAGCCUACCCGG) followed by addition of RNase P protein, the $\mathrm{IC}_{50}$ is about $2 \mu \mathrm{M}$ (Fig. 4). When RNase $\mathrm{P}$ protein is not added to the reactions in which full-length RNase P RNA is renatured in the presence of oligonucleotide, the $\mathrm{IC}_{50}$ for $\mathrm{m}$ (CAGCCUACCCGG) is about $0.013 \mu \mathrm{M}$ (Fig. 4). Evidently, the $\mathrm{IC}_{50} \mathrm{~s}$ are relatively independent of the point at which $\mathrm{m}$ (CAGCCUACCCGG) is added to full-length RNase P RNA, but are increased over 100 -fold by the presence of protein.

The binding site for $\mathrm{m}$ (CAGCCUACCCGG) was determined experimentally by reverse transcription stops in the presence or absence of oligonucleotide. Stops are seen at the binding site because reverse transcriptase is unable to proceed through the oligonucleotide. As expected, m(CAGCCUACCCGG) binds to nucleotides 289-300.

Differences in structure between the functional fold of RNase P RNA and the structure formed in the presence of $\mathrm{m}$ (CAGCCUACCCGG) were probed by diethyl pyrocar- 
TABLE 1. Summary of ODMiR inhibition of pre-tRNA processing by $E$. coli RNase $\mathrm{P}$ and predicted $\Delta \mathrm{G}^{\circ}{ }_{37}{ }^{\prime} \mathrm{s}$ of oligonucleotides binding to E. coli RNase P RNA by the OligoWalk program when RNA refolding is allowed

\begin{tabular}{|c|c|c|c|c|c|c|}
\hline Oligonucleotide & $\begin{array}{c}\text { Region of } \\
\text { complementarity }\end{array}$ & $\begin{array}{c}10 \mu \mathrm{M} \text { DNA } \\
\text { OligoWalk } \\
\Delta \mathrm{G}^{\circ}{ }_{37}\end{array}$ & $\begin{array}{l}\text { Pre-tRNA } \\
\text { processing as } \\
\text { percentage } \\
\text { of control } \\
(10 \mu \mathrm{M} \text { DNA) }\end{array}$ & $\begin{array}{c}1 \mu \mathrm{M} \text { RNA } \\
\text { OligoWalk } \\
\Delta \mathrm{G}^{\circ}{ }_{37}\end{array}$ & $\begin{array}{c}\text { Pre-tRNA } \\
\text { processing as } \\
\text { percentage } \\
\text { of control } \\
(1 \mu \mathrm{M} \\
\left.2^{\prime} \text {-O-Me RNA }\right)\end{array}$ & $\begin{array}{c}\mathrm{IC}_{50}(\mu \mathrm{M}) \text { of } \\
2^{\prime}-O-\mathrm{Me} \text { oligo }\end{array}$ \\
\hline \multicolumn{7}{|c|}{ Oligonucleotides that inhibit ${ }^{a}$} \\
\hline СGGАСТTTССТC & $61-72$ & -5.8 & 55 & -11.4 & 49 & $\sim 1$ \\
\hline ТСАСССТТАССТ & $196-180$ & -10.5 & 53 & -15.7 & 44 & $\sim 1$ \\
\hline TACCGCACCCTT & $181-192$ & -8.6 & 40 & -13.8 & 54 & $\sim 1$ \\
\hline GTTACCAGCCGC & $205-216$ & -6.4 & 33 & -11.8 & 71 & $\sim 3$ \\
\hline GTGCCACGGACT & $217-228$ & -4.7 & 54 & -11.4 & 86 & $\sim 10$ \\
\hline AАССССТАТTTG & $253-264$ & -4.8 & 32 & -9 & 66 & $\sim 10$ \\
\hline CCGTACCTTATG & $265-276$ & -4.2 & 41 & -8.9 & 44 & $\sim 1$ \\
\hline ACCCGGGTTCAG & $283-294$ & & & -11.7 & 49 & $\sim 1$ \\
\hline CAGCCTACCCGG & $289-300$ & -9.5 & 51 & -16.1 & 15 & $\sim 0.2$ \\
\hline CAGCСТАССС & $291-302$ & & & -14.4 & 67 & $\sim 2$ \\
\hline CTCAAGCAGCCT & $295-306$ & & & -19.9 & 48 & $\sim 1$ \\
\hline TCAAGCAGCCT & $296-305$ & & & -18.8 & 96 & $\sim 10$ \\
\hline \multicolumn{7}{|c|}{ Oligonucleotides that do not inhibit } \\
\hline CTGGTCAGCTTC & $1-12$ & -1.3 & 81 & -7.1 & N.D. ${ }^{b}$ & N.D. \\
\hline AGCGGCGACTGT & $13-24$ & -5.8 & 95 & -13.4 & N.D. & N.D. \\
\hline GGACGACGACGA & $25-36$ & 5.2 & 92 & -5.2 & N.D. & N.D. \\
\hline CTCCCCCGAAGA & $37-48$ & -3.2 & 93 & -9.6 & N.D. & N.D. \\
\hline CCCTCCGCCCGT & $49-60$ & -8.9 & 89 & -13.5 & N.D. & N.D. \\
\hline СССТАTGGAGCC & $73-84$ & -9.1 & 85 & -15.7 & N.D. & N.D. \\
\hline CСTGGCACССТG & $85-96$ & -5.7 & 85 & -12.4 & N.D. & N.D. \\
\hline CCCCAGGCGTTA & 97-108 & -4.9 & 104 & -10.1 & N.D. & N.D. \\
\hline CGTGGGTTTCCC & $109-120$ & -7.2 & 100 & -12.4 & N.D. & N.D. \\
\hline TGTTGCACTGGT & $121-132$ & -7.8 & 104 & -14.3 & N.D. & N.D. \\
\hline CGGTTTGCTCTC & $133-144$ & -12.1 & 87 & -17.6 & N.D. & N.D. \\
\hline GCGGGCCATCGG & $145-156$ & -5.7 & 80 & -13.2 & N.D. & N.D. \\
\hline GATCCCGCTTGC & $157-168$ & -6.2 & 87 & -11.7 & N.D. & N.D. \\
\hline GCGGTGCGCTCT & 193-204 & -5.9 & 99 & -12.5 & N.D. & N.D. \\
\hline GTGGAGTTTACC & $229-240$ & -5.5 & 68 & -10.7 & N.D. & N.D. \\
\hline GCCTTGCTCCGG & $241-252$ & -7.7 & 100 & -13.6 & N.D. & N.D. \\
\hline GTTCAGTACGGG & $277-288$ & -4.7 & 98 & -11.5 & N.D. & N.D. \\
\hline CACTGGCTCAAG & $301-312$ & -6.0 & 68 & -13.8 & N.D. & N.D. \\
\hline CCAGCAATCGCT & $313-324$ & -7.0 & 94 & -13.0 & N.D. & N.D. \\
\hline CATTCATCTAGG & $325-336$ & -9.3 & 81 & -15.2 & N.D. & N.D. \\
\hline GTCGTGGACAGT & $337-348$ & -8.9 & 87 & -16.0 & N.D. & N.D. \\
\hline AAGCCGGGTTCT & $349-360$ & -7.4 & 63 & -13.4 & N.D. & N.D. \\
\hline AAACTGACCGAT & $361-372$ & -1.9 & 90 & -9.1 & N.D. & N.D. \\
\hline AGGTGAAACTGA & $366-377$ & 1.2 & 99 & -8.1 & N.D. & N.D. \\
\hline GCACTGTCT & $11-19$ & & & -11.4 & 101 & N.D. \\
\hline ТССТССС & $59-65$ & & & -5.6 & 99 & N.D. \\
\hline TATGGAGCCCG & $71-81$ & & & -13.4 & 102 & N.D. \\
\hline TATGGAG & $75-81$ & & & -4.9 & 89 & N.D. \\
\hline ССТGСССТАТ & $79-88$ & & & -8.9 & 63 & N.D. \\
\hline CCATCGGC & $144-151$ & & & -10.5 & 101 & N.D. \\
\hline СTTACСТGAT & $166-175$ & & & -9.7 & 101 & N.D. \\
\hline CTATTTGGCC & $250-259$ & & & -13.6 & 98 & N.D. \\
\hline
\end{tabular}

${ }^{\mathrm{a}} \mathrm{T}$ is replaced by $\mathrm{U}$ for $2^{\prime}-\mathrm{O}-\mathrm{Me}$ sequences.

b(N.D.) not determined.

bonate (DEPC) modification. DEPC modifies purine N7s (Ehresmann et al. 1987; Doudna and Cech 1995), and therefore is a probe for changes in tertiary structure. As seen in Figures 1 and 5, m(CAGCCUACCCGG) enhances modification at $\mathrm{A}$ residues $65-67,79,81$, and $98-99$.

\section{DISCUSSION}

RNA function has been inhibited by small molecules (Fourmy et al. 1996; Cho et al. 1998; Carter et al. 2000; Jin et al. 2000; Lynch and Puglisi 2001a,b; Kaul and Pilch 2002; 


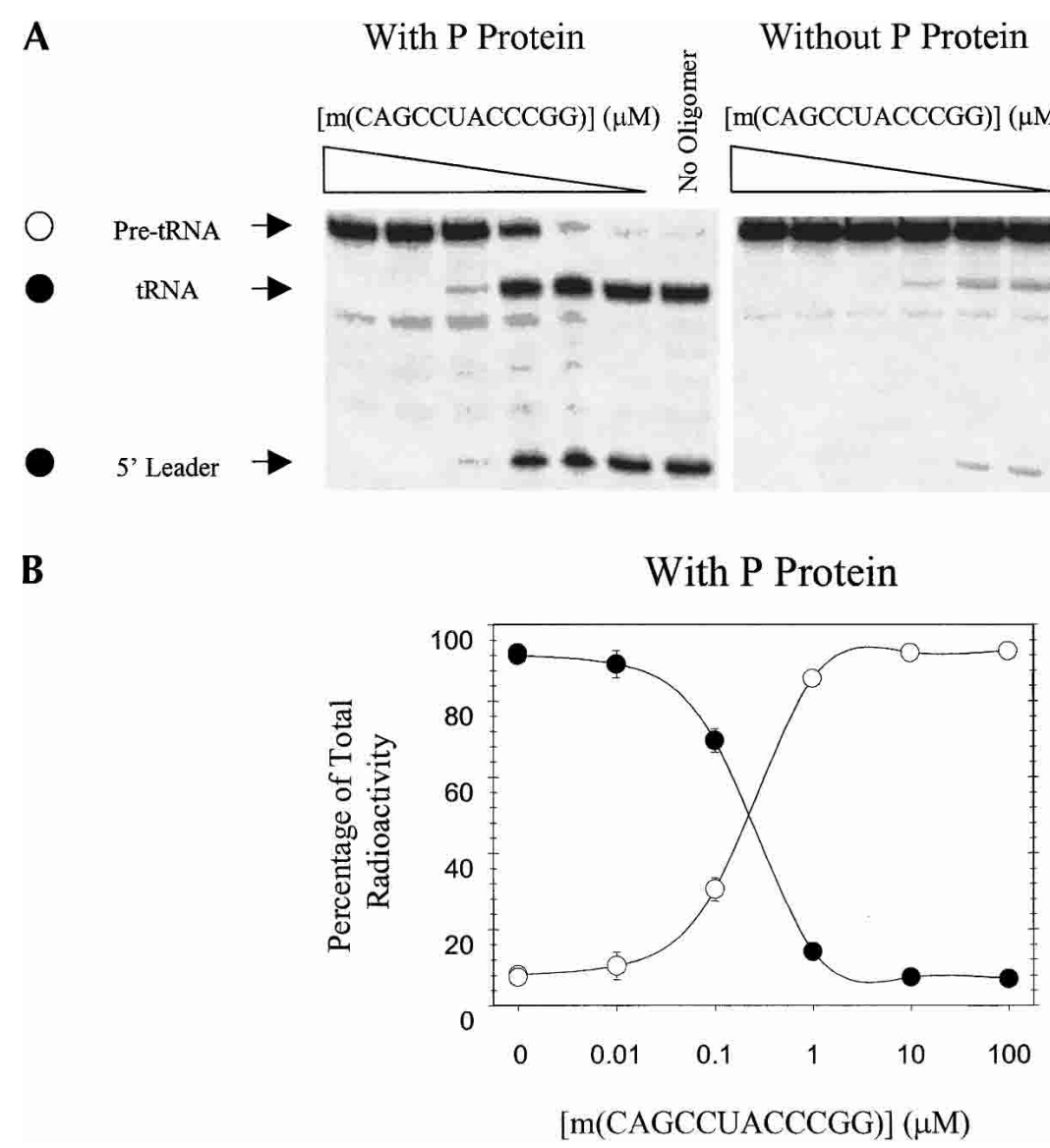

FIGURE 2. Inhibition of processing of B. subtilis pre-tRNA ${ }^{\text {Asp }}$ via ODMiR during transcription of E. coli RNase P RNA. (A) Autoradiogram of a gel for transcriptions in the presence or absence of $\mathrm{m}$ (CAGCCUACCCGG) with RNase P protein (left) and an autoradiogram of a gel for transcriptions in the presence or absence of $m$ (CAGCCUACCCGG) without RNase $P$ protein (right). (B) Plot of the percentage of pre-tRNA (open circles) and processed tRNA (filled circles) as a function of [m(CAGCCUACCCGG)]. All points have error bars, although in some instances they are smaller than the data points.

Vicens and Westhof 2002; Lynch et al. 2003) and oligonucleotide-based therapeutics (Galderisi et al. 1999; Stein 2001; Disney et al. 2003). Oligonucleotide-based therapeutics can be rapidly designed and screened because much is known about molecular recognition between oligonucleotides and RNA, analogs are synthetically accessible (Freier and Altmann 1997), and their pharmacokinetic properties are likely to be similar (Crooke et al. 1996). In principle, insight into regions that can be targeted by oligonucleotidedirected misfolding can be gained from secondary structure prediction (Banerjee and Turner 1995; Pan and Woodson 1998; Mathews et al. 1999a; Chadalavada et al. 2000; Childs et al. 2002). Many RNAs function in RNA-protein complexes, however, and it is possible that the RNA-protein interaction could overcome an oligonucleotide strategy for inhibition. The results in Figure 2 show, however, that a 12-mer oligonucleotide can trap E. coli RNase P RNA during transcription in the presence of RNase $\mathrm{P}$ protein such that it is unable to process a pre-tRNA. Thus, the
ODMiR strategy can be applied to inhibit the function of ribonucleoprotein complexes.

From an oligonucleotide screen of 32 DNA 12-mers, only 8 inhibited at least $40 \%$ of pre-tRNA processing at $10 \mu \mathrm{M}$. Thus, oligonucleotide complementarity to RNase P RNA is not sufficient for inhibition.

The most efficient oligonucleotide, $\mathrm{m}$ (CAGCCUACCCGG), inhibited $E$. coli RNase $\mathrm{P}$ function with an $\mathrm{IC}_{50}$ of about $200 \mathrm{nM}$ (Fig. 2). This oligonucleotide (approximated as an RNA oligonucleotide) is predicted by the program OligoWalk (Mathews et al. 1999a) to have a total binding free energy of $-16.1 \mathrm{kcal} / \mathrm{mole}$, corresponding to a $K_{d}$ of $5 \mathrm{pM}$, when the RNA is allowed to refold. Only one other 12-mer oligonucleotide tested is predicted to bind more tightly (Table 1). Of all 366 possible 12 -mers, it ranks in the top $12 \%$ of oligonucleotides for favorable binding free energy. Thus, computer algorithms may be useful for identifying sequences worth screening even when the native structure has pseudoknots, which are not allowed by the algorithm (Zuker 1989). The more than 10,000-fold difference between measured $\mathrm{IC}_{50}$ and predicted $K_{d}$ with refolding, however, indicates that there are many complexities not included in the algorithm. If refolding is not allowed, then the predicted $\mathrm{K}_{\mathrm{d}}$ is about $1 \mathrm{nM}$.

The predicted binding free energy of $-16.1 \mathrm{kcal} / \mathrm{mole}$ for $\mathrm{m}$ (CAGCCUACCCGG) can be compared with the $K_{d}$ of 0.4 $\mathrm{nM}$ measured for RNase P protein binding to RNase P RNA under similar salt conditions (Talbot and Altman 1994b). This $K_{d}$ corresponds to a $\Delta \mathrm{G}^{\circ}{ }_{37}$ of $-13.3 \mathrm{kcal} / \mathrm{mole}$. If oligonucleotide inhibition of function required complete displacement of RNase P protein, then the expected free energy of binding would be $-16.1+13.3=-2.8 \mathrm{kcal} / \mathrm{mole}$, corresponding to a $K_{d}$ of $\sim 10 \mathrm{mM}$. The least favorable $\mathrm{IC}_{50}$ for inhibition by $\mathrm{m}$ (CAGCCUACCCGG) is $3 \mu \mathrm{M}$. Evidently, the protein is still able to bind in the presence of $\mathrm{m}$ (CAGC CUACCCGG).

In a previous study of ODMiR inhibition of group I intron self-splicing (Childs et al. 2002), a successful 8-mer was designed on the basis of predicted suboptimal foldings of the intron. Several 2'-O-Me oligonucleotides were designed in a similar way for RNase P RNA, but only one inhibited activity at $10 \mu \mathrm{M}$. Evidently, our knowledge of RNA folding in the presence of pseudoknots and protein is 
insufficient for completely directed design of ODMiR oligonucleotides.

The m(CAGCCUACCCGG) oligonucleotide binds to nt 289-300 ( $3^{\prime}$ side of J15/16) as designed. It base pairs with a number of residues that have been implicated in pre-tRNA recognition, including G291, G292, and U294. In the current model, G291 forms a base triple with G259 in RNase P RNA and A76 in pre-tRNA; G292 forms a base triple with A258 in RNase P RNA and C75 in pretRNA; and U294 in RNase P RNA binds to R73 in pre-tRNA, where R is A or G (Kirsebom and Svard 1994; Heide et al. 2001). There is evidence that $J 15 / 16$ is also a metal-ion-binding site (Kazakov and Altman 1991; Zito et al. 1993; Ciesiolka et al. 1994; Kufel and Kirsebom 1994). Part of the mode of inhibition may be competing with the pre-tRNA for this binding site or interfering with metal ion binding. Structure probing with DEPC, however, shows a significant structural rearrangement in L8 (A's 98-99), J5/6 (A79 and A81), and the single-stranded region between $\mathrm{P} 3$ and P4 (A's 65-67; Figs. 1, 5). Moreover, the $\mathrm{IC}_{50}$ for inhibition increases roughly $10-$ fold when m(CAGCCUACCCGG) is added to full-length RNase P RNA complexed with protein rather than to a transcription reaction. This suggests that oligonucleotide directed misfolding is the main mode of action.

A's 65-67 are part of the pseudoknot containing P4 (Haas et al. 1991), and are important for catalytic activity (Kazantsev and Pace 1998). A's 98 and 99 in L8 are predicted to be involved in a tertiary interaction with P4 (Massire et al. 1998). Thus, increased modification of A's 65-67, 98 , and 99 by DEPC suggests a structural rearrangement of part of the P4 pseudoknot. A's 79 and 81 are in close proximity to the 4 bp of P6, which is also part of a pseudoknot (James et al. 1988). Deletion studies of RNase P RNA show that disruption of P6 increases the $K_{M}$ for pre-tRNA (Darr et al. 1992).

Improvements to secondary structure prediction and in understanding how large RNAs fold should eventually allow for selection of ODMiR targets from entire genomes. Such RNAs may include RNAs with secondary or tertiary structures important for catalysis, regulation of translation, localization, or interaction with other biomolecules.

\section{MATERIALS AND METHODS}

\section{Buffers}

HXMg is $50 \mathrm{mM}$ HEPES $\left(25 \mathrm{mM} \mathrm{Na}^{+}\right), 135 \mathrm{mM} \mathrm{KCl}$, and $X \mathrm{mM}$
$\mathrm{MgCl}_{2}$. Transcription buffer contains $1 \times \mathrm{H} 14 \mathrm{Mg}, 1 \mathrm{mM}$ each NTP, $2 \mathrm{mM}$ DTT, and $2 \mathrm{mM}$ spermidine.

\section{RNA and protein plasmids}

Plasmids containing the E. coli RNase P RNA (M1) gene (pDW98) and RNase $\mathrm{P}$ protein $(\mathrm{C} 5)$ gene ( $\mathrm{pECPE} 1)$, and the $B$. subtilis pre-tRNA $^{\text {Asp }}$ gene (pDW152; Beebe and Fierke 1994) were generously supplied by Norman R. Pace (University of Colorado, Boulder).

\section{Oligonucleotides}

Oligonucleotides were synthesized, deblocked, and purified by standard methods (Matteucci and Caruthers 1980; Caruthers et al. 1992; Xia et al. 1998). Concentrations were determined from predicted extinction coefficients and measured absorbances at 260 or $280 \mathrm{~nm}$ at $25^{\circ} \mathrm{C}$ (Puglisi and Tinoco 1989).

\section{Preparation of $E$. coli RNase P protein}

RNase P protein was expressed and purified by the method of A.W. Poole and N.R. Pace (pers. comm.). The RNase P protein plasmid was transformed into BL21 (DE3) pLysS cells 
A

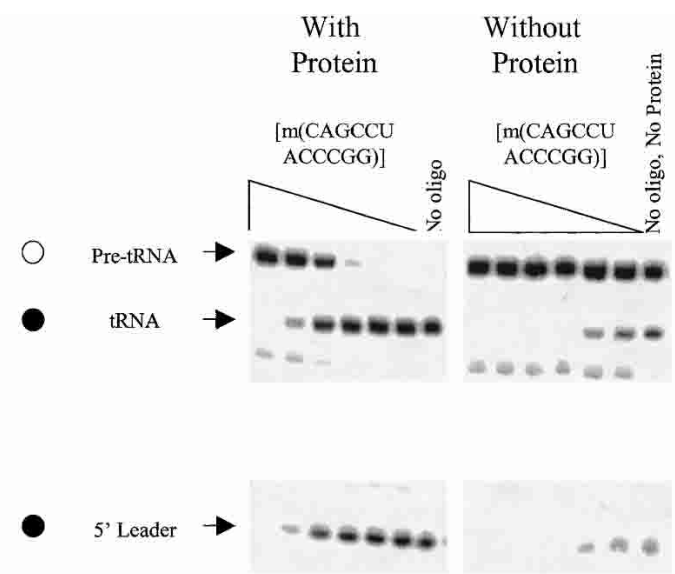

B

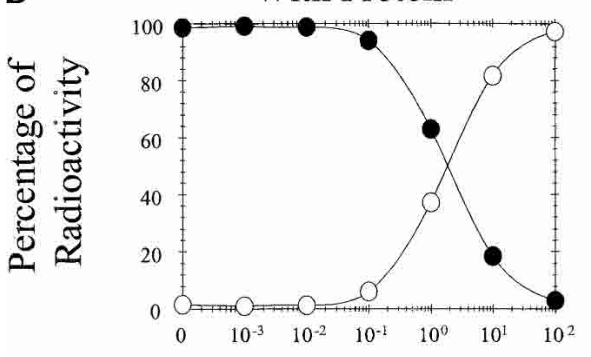

[m(CAGCCUACCCGG)], $\mu \mathrm{M}$

FIGURE 4. Inhibition of processing of $B$. subtilis pre-tRNA when full-length RNase P RNA is renatured in the presence of $\mathrm{m}$ (CAGCCUACCCGG). (A) Autoradiogram of a gel in which RNase P RNA was renatured in the presence of $\mathrm{m}$ (CAGCCUACCCGG). (Left) RNase P protein added after renaturation; (right) RNase P protein not added after renaturation. (B) Plot of the percentage of pre-tRNA (open circles) and processed tRNA (filled circles) as a function of [m(CAGCCUACCCGG)]. All points have error bars, although in some instances they are smaller than the data points.

for expression. Protein expression was induced by addition of 1 $\mathrm{mM}$ IPTG and incubation for $4 \mathrm{~h}$ at $37^{\circ} \mathrm{C}$. Cells were lysed by sonication in $50 \mathrm{mM}$ Tris- $\mathrm{HCl}(\mathrm{pH} 8.0), 5 \mathrm{mM}$ EDTA, $100 \mathrm{mM}$ DTT, and $10 \%$ glycerol. Lysate was brought to final concentrations of $5 \mathrm{M}$ urea, $50 \mathrm{mM} \mathrm{NaCl}, 50 \mathrm{mM}$ Tris- $\mathrm{HCl}(\mathrm{pH} 8.0)$, and $51 \mathrm{mM}$ DTT and purified on an SP Sepharose column (Amersham) using
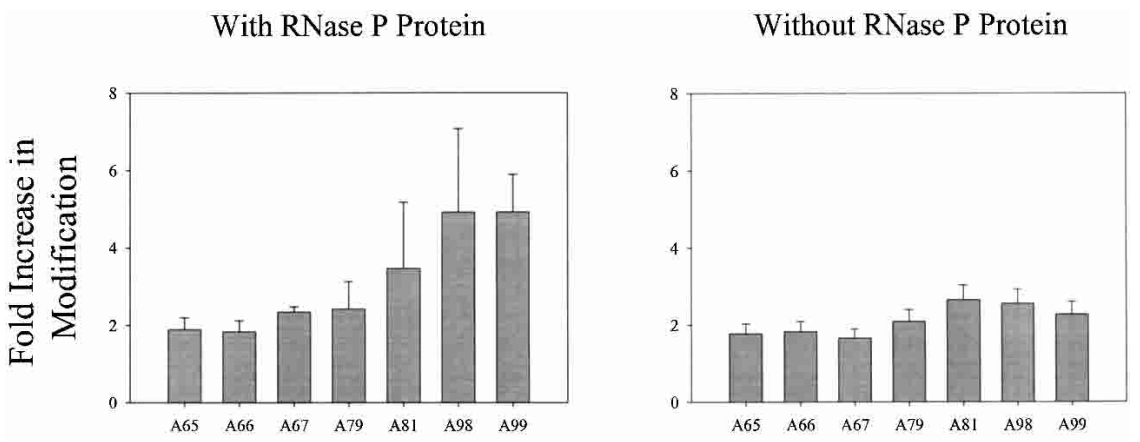

\section{Nucleotide Position}

FIGURE 5. Plots of the fold increase in DEPC modification at A residues 65-67, 79, 81, 98, and 99 in the presence (left) or absence (right) of RNase P protein when m(CAGCCUAC CCGG) is present.

\section{Oligonucleotide screen and dose-response curves}

Transcription reactions were run in $20 \mu \mathrm{L}$ containing $1 \times$ transcription buffer, $50 \mathrm{U}$ T7 RNA polymerase, $100 \mathrm{ng}$ linearized RNase P RNA plasmid, with or without $5 \mathrm{ng}$ of RNase P protein, and trace internally labeled pre-tRNA annealed as above. Transcription mixtures with and without ODMiR oligonucleotides and with or without RNase $P$ protein were incubated for $1 \mathrm{~h}$ at $37^{\circ} \mathrm{C}$, and then were ethanol precipitated. Products were separated on an $8 \%$ polyacrylamide denaturing gel. Results were quantified with a phosphorimager and ImageQuant v5.2. $\mathrm{IC}_{50} \mathrm{~s}$ were obtained by fitting dose-response curves to a four-parameter logistic curve (SigmaPlot 2001).

To determine the concentration of RNase P RNA transcribed in a $20-\mu \mathrm{L}$ transcription reaction, $100 \mathrm{ng}$ of linearized RNase P RNA plasmid was transcribed for $1 \mathrm{~h}$ at $37^{\circ} \mathrm{C}$ in $1 \times$ transcription buffer with $50 \mathrm{U}$ T7 RNA polymerase, and $1 \mu \mathrm{Ci}(3000 \mathrm{Ci} /$ mmole $)$ $\left[\alpha-{ }^{32} \mathrm{P}\right]$ ATP. The full-length product was compared to $1 \mu \mathrm{Ci}$ of $\left[\alpha-{ }^{32} \mathrm{P}\right] \mathrm{ATP}$, and the 
concentration of full-length product was calculated to be about $2 \mathrm{nM}$.

\section{Inhibition of full-length RNase P RNA by $\mathbf{m}$ (CAGCCUACCCGG)}

The m(CAGCCUACCCGG) was also tested for inhibition of RNase $\mathrm{P}$ activity by renaturing RNase $\mathrm{P}$ RNA followed by addition of $\mathrm{m}$ (CAGCCUACCCGG) with and without RNase P protein. RNase P RNA was renatured in $1 \times \mathrm{H} 0 \mathrm{Mg}$ buffer at $90^{\circ} \mathrm{C}$ for $3 \mathrm{~min}$, followed by slow cooling to $37^{\circ} \mathrm{C}$. $\mathrm{MgCl}_{2}$ was added to $10 \mathrm{mM}$ along with various concentrations of oligonucleotide. If included in the reactions, $5 \mathrm{ng}$ of RNase P protein were added per $20 \mu \mathrm{L}$. Samples were incubated for $45 \mathrm{~min}$ at $37^{\circ} \mathrm{C}$, and then renatured pre-tRNA was added. Samples were quenched with 2.5 volumes of ethanol after incubation for $1 \mathrm{~h}$ at $37^{\circ} \mathrm{C}$. Experiments were also done in a similar manner but by renaturing RNase P RNA in the presence of $\mathrm{m}$ (CAGCCUACCCGG) with or without RNase P protein.

\section{Diethyl pyrocarbonate probing}

Structural changes due to ODMiR oligonucleotides were probed with DEPC by annealing $44 \mathrm{nM}$ RNase P RNA with or without 10 $\mu \mathrm{M}$ m(CAGCCUACCCGG) for $3 \mathrm{~min}$ at $90^{\circ} \mathrm{C}$, followed by slow cooling to $37^{\circ} \mathrm{C} . \mathrm{MgCl}_{2}$ was added to $10 \mathrm{mM}$, and RNase P protein, if included, was added to $5 \mathrm{ng}$ per $20 \mu \mathrm{L}$ to give $1: 1$ stoichiometry. Samples were incubated for $45 \mathrm{~min}$ at $37^{\circ} \mathrm{C}$, and then renatured pre-tRNA was added. The samples were equilibrated for $45 \mathrm{~min}$ at $37^{\circ} \mathrm{C}$. DEPC was added to $650 \mathrm{mM}$ and the samples were incubated for $20 \mathrm{~min}$ at $37^{\circ} \mathrm{C}$. The reactions were quenched by addition of 2.5 volumes of ethanol (Banerjee and Turner 1995). RNase P RNA was ethanol precipitated and reverse transcribed to detect sites of modification. RNase P RNA was sequenced by the Sanger method with reverse transcriptase (Sanger et al. 1977). Structural changes for nucleotides were reported if there was at least a 1.9-fold increase in modification when normalized to fulllength product.

\section{OligoWalk predictions}

The $\Delta \mathrm{G}_{37}^{\circ} \mathrm{s}$ of duplex formation between all possible 12-mer oligonucleotides and RNase P RNA were calculated by the OligoWalk program (Mathews et al. 1999a) with the following parameters: refold RNA, include suboptimal structures (predicted from the RNAstructure program; Mathews et al. 1999b), and DNA at $10 \mu \mathrm{M}$ or RNA (approximation for 2'-O-Me RNA oligonucleotides) at 1 $\mu \mathrm{M}$ concentration.

\section{ACKNOWLEDGMENTS}

The authors thank Norman Pace (University of Colorado, Boulder) for generously supplying all the plasmids used in this work and for helpful discussions, and Robert Bambara and Hui-I Kao for assistance with protein purification. This work was supported by NIH Grant GM22939 to D.H.T. J.L.C. was partially supported by NIH Grant T32 DE07202.

The publication costs of this article were defrayed in part by payment of page charges. This article must therefore be hereby marked "advertisement" in accordance with 18 USC section 1734 solely to indicate this fact.

Received April 28, 2003; accepted September 11, 2003.

\section{REFERENCES}

Altman, S., Kirsebom, L., and Talbot, S. 1993. Recent studies of ribonuclease P. FASEB J. 7: 7-14.

Ban, N., Nissen, P., Hansen, J., Moore, P.B., and Steitz, T.A. 2000. The complete atomic structure of the large ribosomal subunit at $2.4 \AA$ resolution. Science 289: 905-920.

Banerjee, A.R. and Turner, D.H. 1995. The time dependence of chemical modification reveals slow steps in the folding of a group I ribozyme. Biochemistry 34: 6504-6512.

Beebe, J.A. and Fierke, C.A. 1994. A kinetic mechanism for cleavage of precursor tRNA(Asp) catalyzed by the RNA component of Bacillus subtilis ribonuclease P. Biochemistry 33: 10294-10304.

Been, M.D., Perrotta, A.T., and Rosenstein, S.P. 1992. Secondary structure of the self-cleaving RNA of hepatitis delta-virus: Applications to catalytic RNA design. Biochemistry 31: 11843-11852.

Brown, J.W. 1999. The ribonuclease P database. Nucleic Acids Res. 27: 314 .

Carter, A.P., Clemons, W.M., Brodersen, D.E., Morgan-Warren, R.J., Wimberly, B.T., and Ramakrishnan, V. 2000. Functional insights from the structure of the $30 \mathrm{~S}$ ribosomal subunit and its interactions with antibiotics. Nature 407: 340-348.

Caruthers, M.H., Beaton, G., Wu, J.V., and Wiesler, W. 1992. Chemical synthesis of deoxyoligonucleotides and deoxyoligonucleotide analogs. Methods Enzymol. 211: 3-20.

Celander, D.W. and Cech, T.R. 1991. Visualizing the higher-order folding of a catalytic RNA molecule. Science 251: 401-407.

Chadalavada, D.M., Knudsen, S.M., Nakano, S., and Bevilacqua, P.C. 2000. A role for upstream RNA structure in facilitating the catalytic fold of the genomic hepatitis delta virus ribozyme. J. Mol. Biol. 301: 349-367.

Chadalavada, D.M., Senchak, S.E., and Bevilacqua, P.C. 2002. The folding pathway of the genomic hepatitis delta virus ribozyme is dominated by slow folding of the pseudoknots. J. Mol. Biol. 317: 559-575.

Childs, J.L., Disney, M.D., and Turner, D.H. 2002. Oligonucleotide directed misfolding of RNA inhibits Candida albicans group I intron splicing. Proc. Natl. Acad. Sci. 99: 11091-11096.

Cho, J., Hamasaki, K., and Rando, R.R. 1998. The binding site of a specific aminoglycoside binding RNA molecule. Biochemistry 37: 4985-4992.

Ciesiolka, J., Hardt, W.D., Schlegl, J., Erdmann, V.A., and Hartmann, R.K. 1994. Lead-ion-induced cleavage of RNase P RNA. Eur. J. Biochem. 219: 49-56.

Clodi, E., Semrad, K., and Schroeder, R. 1999. Assaying RNA chaperone activity in vivo using a novel RNA folding trap. EMBO J. 18: $3776-3782$.

Crooke, S.T., Graham, M.J., Zuckerman, J.E., Brooks, D., Conklin, B.S., Cummins, L.L., Greig, M.J., Guinosso, C.J., Kornbrust, D., Manoharan, M., et al. 1996. Pharmacokinetic properties of several novel oligonucleotide analogs in mice. J. Pharmacol. Exp. Ther. 277: 923-937.

Darr, S.C., Zito, K., Smith, D., and Pace, N.R. 1992. Contributions of phylogenetically variable structural elements to the function of the ribozyme ribonuclease-P. Biochemistry 31: 328-333.

Disney, M.D., Matray, T., Gryaznov, S.M., and Turner, D.H. 2001. Binding enhancement by tertiary interactions and suicide inhibition of a Candida albicans group I intron by phosphoramidate and 2'-O-Methyl hexanucleotides. Biochemistry 40: 6520-6526.

Disney, M.D., Haidaris, C.G., and Turner, D.H. 2003. Uptake and antifungal activity of oligonucleotides in Candida albicans. Proc. Natl. Acad. Sci. 100: 1530-1534.

Doudna, J.A. and Cech, T.R. 1995. Self-assembly of a group I intron 
active site from its component tertiary structural domains. RNA 1: 36-45.

Ehresmann, C., Baudin, F., Mougel, M., Romby, P., Ebel, J.P., and Ehresmann, B. 1987. Probing the structure of RNAs in solution. Nucleic Acids Res. 15: 9109-9128.

Fang, X.W., Pan, T., and Sosnick, T.R. 1999. Mg2+-dependent folding of a large ribozyme without kinetic traps. Nat. Struct. Biol. 6: 10911095.

Fang, X.W., Thiyagarajan, P., Sosnick, T.R., and Pan, T. 2002. The rate-limiting step in the folding of a large ribozyme without kinetic traps. Proc. Natl. Acad. Sci. 99: 8518-8523.

Fedor, M.J. and Uhlenbeck, O.C. 1990. Substrate sequence effects on hammerhead RNA catalytic efficiency. Proc. Natl. Acad. Sci. 87: $1668-1672$.

Fire, A., Xu, S., Montgomery, M.K., Kostas, S.A., Driver, S.E., and Mello, C.C. 1998. Potent and specific genetic interference by double-stranded RNA in Caenorhabditis elegans. Nature 391: 806811.

Fourmy, D., Recht, M.I., Blanchard, S.C., and Puglisi, J.D. 1996. Structure of the A site of Escherichia coli 16S ribosomal RNA complexed with an aminoglycoside antibiotic. Science 274: 1367-1371.

Freier, S.M. and Altmann, K.H. 1997. The ups and downs of nucleic acid duplex stability: Structure-stability studies on chemicallymodified DNA:RNA duplexes. Nucleic Acids Res. 25: 44294443.

Galderisi, U., Cascino, A., and Giordano, A. 1999. Antisense oligonucleotides as therapeutic agents. J. Cell. Physiol. 181: 251-257.

Guerrier-Takada, C., Gardiner, K., Marsh, T., Pace, N., and Altman, S. 1983. The RNA moiety of ribonuclease-P is the catalytic subunit of the enzyme. Cell 35: 849-857.

Haas, E.S., Morse, D.P., Brown, J.W., Schmidt, F.J., and Pace, N.R. 1991. Long-range structure in ribonuclease P RNA. Science 254: 853-856.

Heide, C., Feltens, R., and Hartmann, R.K. 2001. Purine N7 groups that are crucial to the interaction of Escherichia coli RNase P RNA with tRNA. RNA 7: 958-968.

Hermann, T. and Westhof, E. 1998. RNA as a drug target: Chemical, modelling, and evolutionary tools. Curr. Opin. Biotechnol. 9: 6673.

James, B.D., Olsen, G.J., Liu, J.S., and Pace, N.R. 1988. The secondary structure of ribonuclease P RNA, the catalytic element of a ribonucleoprotein enzyme. Cell 52: 19-26.

Jin, E., Katritch, V., Olson, W.K., Kharatisvili, M., Abagyan, R., and Pilch, D.S. 2000. Aminoglycoside binding in the major groove of duplex RNA: The thermodynamic and electrostatic forces that govern recognition. J. Mol. Biol. 298: 95-110.

Kaul, M. and Pilch, D.S. 2002. Thermodynamics of aminoglycosiderRNA recognition: The binding of neomycin-class aminoglycosides to the A site of 16S rRNA. Biochemistry 41: 7695-7706.

Kazakov, S. and Altman, S. 1991. Site-specific cleavage by metal ion cofactors and inhibitors of M1 RNA, the catalytic subunit of RNase P from Escherichia coli. Proc. Natl. Acad. Sci. 88: 9193-9197.

Kazantsev, A.V. and Pace, N.R. 1998. Identification by modificationinterference of purine N-7 and ribose $2^{\prime}-\mathrm{OH}$ groups critical for catalysis by bacterial ribonuclease P. RNA 4: 937-947.

Kirsebom, L.A. and Svard, S.G. 1994. Base pairing between Escherichia coli RNase P RNA and its substrate. EMBO J. 13: 4870-4876.

Kole, R. and Altman, S. 1979. Reconstitution of RNase P activity from inactive RNA and protein. Proc. Natl. Acad. Sci. 76: 3795-3799.

Kufel, J. and Kirsebom, L.A. 1994. Cleavage site selection by M1 RNA the catalytic subunit of Escherichia coli RNase P, is influenced by pH. J. Mol. Biol. 244: 511-521.

Lambowitz, A.M. and Perlman, P.S. 1990. Involvement of aminoacyltRNA synthetases and other proteins in group I and group II intron splicing. Trends Biochem. Sci. 15: 440-444.

Lynch, S.R. and Puglisi, J.D. 2001a. Structural origins of aminoglycoside specificity for prokaryotic ribosomes. J. Mol. Biol. 306: 10371058.

-2001b. Structure of a eukaryotic decoding region A-site RNA.
J. Mol. Biol. 306: 1023-1035.

Lynch, S.R., Gonzalez, R.L., and Puglisi, J.D. 2003. Comparison of $\mathrm{X}$-ray crystal structure of the $30 \mathrm{~S}$ subunit-antibiotic complex with NMR structure of decoding site oligonucleotide-paromomycin complex. Structure 11: 43-53.

Massire, C., Jaeger, L., and Westhof, E. 1998. Derivation of the threedimensional architecture of bacterial ribonuclease P RNAs from comparative sequence analysis. J. Mol. Biol. 279: 773-793.

Mathews, D.H., Burkard, M.E., Freier, S.M., Wyatt, J.R., and Turner, D.H. 1999a. Predicting oligonucleotide affinity to nucleic acid targets. RNA 5: 1458-1469.

Mathews, D.H., Sabina, J., Zuker, M., and Turner, D.H. 1999b. Expanded sequence dependence of thermodynamic parameters improves prediction of RNA secondary structure. J. Mol. Biol. 288: 911-940.

Matteucci, M.D. and Caruthers, M.H. 1980. The synthesis of oligodeoxypyrimidines on a polymer support. Tetrahedron Lett. 21: 719722.

Montgomery, M.K., Xu, S., and Fire, A. 1998. RNA as a target of double-stranded RNA-mediated genetic interference in Caenorhabditis elegans. Proc. Natl. Acad. Sci. 95: 15502-15507.

Myers, C.A., Wallweber, G.J., Rennard, R., Kemel, Y., Caprara, M.G., Mohr, G., and Lambowitz, A.M. 1996. A tyrosyl-tRNA synthetase suppresses structural defects in the two major helical domains of the group I intron catalytic core. J. Mol. Biol. 262: 87-104.

Noller, H.F., Hoffarth, V., and Zimniak, L. 1992. Unusual resistance of peptidyl transferase to protein extraction procedures. Science 256: $1416-1419$.

Nykanen, A., Haley, B., and Zamore, P.D. 2001. ATP requirements and small interfering RNA structure in the RNA interference pathway. Cell 107: 309-321.

Pace, N.R. and Brown, J.W. 1995. Evolutionary perspective on the structure and function of ribonuclease $\mathrm{P}$, a ribozyme. J. Bacteriol. 177: 1919-1928.

Pan, T. and Sosnick, T.R. 1997. Intermediates and kinetic traps in the folding of a large ribozyme revealed by circular dichroism and UV absorbance spectroscopies and catalytic activity. Nat. Struct. Biol. 4: 931-938.

Pan, J. and Woodson, S.A. 1998. Folding intermediates of a self-splicing RNA: Mispairing of the catalytic core. J. Mol. Biol. 280: 597-609.

Pan, T., Fang, X., and Sosnick, T.R. 1999. Pathway modulation, circular permutation and rapid RNA folding under kinetic control. $J$. Mol. Biol. 286: 721-731.

Pearson, N.D. and Prescott, C.D. 1997. RNA as a drug target. Chem. Biol. 4: 409-414.

Puglisi, J.D. and Tinoco Jr., I. 1989. Absorbance melting curves of RNA. Methods Enzymol. 180: 304-325.

Russell, R., Zhuang, X., Babcock, H.P., Millett, I.S., Doniach, S., Chu, S., and Herschlag, D. 2002. Exploring the folding landscape of a structured RNA. Proc. Natl. Acad. Sci. 99: 155-160.

Sanger, F., Nicklen, S., and Coulson, A.R. 1977. DNA sequencing with chain-terminating inhibitors. Proc. Natl. Acad. Sci. 74: 5436-5467.

Stark, B.C., Kole, R., Bowman, E.J., and Altman, S. 1978. Ribonuclease P: An enzyme with an essential RNA component. Proc. Natl. Acad. Sci. 75: 3717-3721.

Stein, C.A. 2001. Antisense that comes naturally. Nat. Biotechnol. 19: 737-738.

Talbot, S.J. and Altman, S. 1994a. Gel retardation analysis of the interaction between C5 protein and M1 RNA in the formation of the ribonuclease P holoenzyme from Escherichia coli. Biochemistry 33: 1399-1405.

- 1994b. Kinetic and thermodynamic analysis of RNA-protein interactions in the RNase P holoenzyme from Escherichia coli. Biochemistry 33: 1406-1411.

Testa, S.M., Gryaznov, S.M., and Turner, D.H. 1999. In vitro suicide inhibition of self-splicing of a group I intron from Pneumocystis carinii by an $\mathrm{N}^{\prime} \rightarrow \mathrm{P}^{\prime}$ phosphoramidate hexanucleotide. Proc. Natl. Acad. Sci. 96: 2734-2739.

Vicens, Q. and Westhof, E. 2002. Crystal structure of a complex be- 
tween the aminoglycoside tobramycin and an oligonucleotide containing the ribosomal decoding A site. Chem. Biol. 9: 747-755.

Walstrum, S.A. and Uhlenbeck, O.C. 1990. The self-splicing RNA of Tetrahymena is trapped in a less active conformation by gel purification. Biochemistry 29: 10573-10576.

Webb, A.E., Rose, M.A., Westhof, E., and Weeks, K.M. 2001. Proteindependent transition states for ribonucleoprotein assembly. J. Mol. Biol. 309: 1087-1100.

Weeks, K.M. and Cech, T.R. 1995a. Efficient protein-facilitated splicing of the yeast mitochondrial bI5 intron. Biochemistry 34: 7728-7738.

. 1995b. Protein facilitation of group I intron splicing by assembly of the catalytic core and the $5^{\prime}$ splice site domain. Cell 82: $221-230$.

Xia, T., SantaLucia Jr., J., Burkard, M.E., Kierzek, R., Schroeder, S.J.,
Jiao, X., Cox, C., and Turner, D.H. 1998. Thermodynamic parameters for an expanded nearest-neighbor model for formation of RNA duplexes with Watson-Crick base pairs. Biochemistry 37: 14719-14735.

Zarrinkar, P.P., Wang, J., and Williamson, J.R. 1996. Slow folding kinetics of RNase P RNA. RNA 2: 564-573.

Zhang, F., Ramsay, E.S., and Woodson, S.A. 1995. In vivo facilitation of Tetrahymena group I intron splicing in Escherichia coli preribosomal RNA. RNA 1: 284-292.

Zito, K., Huttenhofer, A., and Pace, N.R. 1993. Lead-catalyzed cleavage of ribonuclease-P RNA as a probe for integrity of tertiary structure. Nucleic Acids Res. 21: 5916-5920.

Zuker, M. 1989. On finding all suboptimal foldings of an RNA molecule. Science 244: 48-52. 

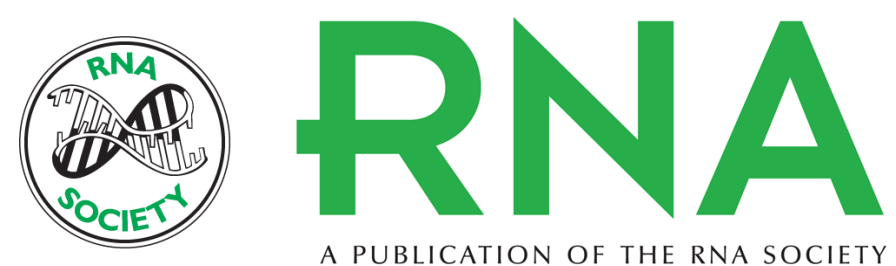

A PUBLICATION OF THE RNA SOCIETY

\title{
Inhibition of Escherichia coli RNase P by oligonucleotide directed misfolding of RNA
}

\author{
JESSICA L. CHILDS, ALEX W. POOLE and DOUGLAS H. TURNER
}

RNA 2003 9: 1437-1445

References This article cites 75 articles, 25 of which can be accessed free at: http://rnajournal.cshlp.org/content/9/12/1437.full.html\#ref-list-1

\section{License}

Email Alerting Service

Receive free email alerts when new articles cite this article - sign up in the box at the top right corner of the article or click here. 